\title{
Social Interaction and Communication in Multicultural Counseling
}

\author{
Marssel Michael Sengkey* \\ Department of Psychology \\ Universitas Negeri Manado \\ Manado, Indonesia \\ *mmsengkey@unima.ac.id
}

\author{
Mint Husen Raya Aditama \\ Department of Guidance Counseling \\ Universitas Negeri Manado \\ Manado, Indonesia \\ husenmint@unima.ac.id
}

\author{
Tellma Mona Tiwa \\ Department of Psychology \\ Universitas Negeri Manado \\ Manado, Indonesia \\ tellmatiwa@unima.ac.id
}

\begin{abstract}
This paper discusses the relevance of social interaction and student communication theories with a culture inherent to the student's personal. An idealism born from an early culture affects how communication and interaction of one person is. The problems in cultural bias that arise in student interaction and communication are a major concern in seeing how the early cultural roles of the globalization era still affect one's interactions and communication. This paper helps us understand how cultures that are owned on self-counsellors influence the concept of problem solving in the counseling process. The arguments that support these aspects of cultural theory will be explained through the three concepts of a comparative study approach, namely communication in crosscultural counseling, culture in the organization, and assimilation of cultural/cultural constructions.
\end{abstract}

Keywords: communication in culture, cross-cultural counseling, cultural psychology

\section{INTRODUCTION}

Assuming that there are differences in values and cultural norms in multicultural students, this comparative study is specialized in the aspects of social interaction and counseling of students. These aspects are, communication in cross-cultural counseling, culture within the organization, and assimilation of cultural/cultural constructions. The emphasis on the content of this article is more a cross-cultural counseling comparison study that contains how cultural values and norms can affect someone in interacting and communicating in counseling and organizations. Cross-cultural psychology is a study of the similarities and differences in the psychological functions of a person in various cultures and ethno-cultural groups [1].

Cross-cultural psychology studies look to behave and cultured to have two perceptions, first, cross-cultural differences to be a general view and can be explained through psychological mechanisms. Secondly, cross-cultural values cannot be measured through psychological instruments or other instruments, as cultural values are inherent in the culture itself. The second perception may be very opposite when referring to the nature of the culture itself. Because culture is essentially the result of a situation that has been done by humans so that it becomes a rule or an idea [2]. On the theoretical foundation of cross-cultural psychology, psychological and behavioral processes cannot be separated from culture [2]. In other studies, culture is regarded as a joint consensus in a group or is a result of cultural construction [3].

Culture is the result of behavior. Culture is the symbols inherent and possessed by every human being. Culture binds individuals so that he can act in accordance with their trusted norms and values in the community. The culture created by the community will distinguish one community from another [4]. In other words, the culture is the identity that is brought from birth to death and is believed to be the thing that affects the values and norms of the individual with the other.

The values and norms contained in culture are symbols depicting personal characteristics and human social structures. Value is an aspect of the culture that determines the rules in a group. In certain social structures individual relationships with social groups are limited by a value that binds uninscribed. The value of that culture is believed to be their hallmark and identity [5]. The cultural value of each individual also affects the communication process. It is also called intercultural communication.

Intercultural communication occurs when two different cultural groups communicate with each other without barriers [6]. The process intercultural communication occurs when there is communication occurring in two or more persons with different cultural backgrounds [7]. Intercultural communication states that inter-cultural communication occurs when there are 
two different cultures and both cultures are conducting the process of communication. In intercultural communication, language becomes an important point where the person's concerns in delivering the message will be limited by unaligned communication. Intercultural communication has the consequences of cultural bias, the cultural bias in question can be addressed using a single language to communicate, although not a few of them still use their regional language in communicating [8].

Training language is the basis for communication and growing awareness of tolerance in intercultural communication. Using one language (national language) in communicating will be more effective when compared to using regional language which error prone to interpret [9]. The use of language in intercultural communication for students in north Sulawesi province, for example, newest students who are students in the status of migrants will use basic language or Indonesian national language to interact. But it does not close the possibility of gradually using the local language because of the demands of tolerance in communication itself. With the passage of time, there will be a process of internationalization and changes in the language of association adopted [9]. This can be attributed to the language assimilation process.

The language dimension in intercultural communication is unique because it does not cling to national cultural definitions. Such problems draw the author's attention to a question what ' culture ' is, what its purpose is, how deep culture is inherent to them, and how willing they adapt it in different cultures. Therefore, the authors will try to upload it in 3 dimensions of culture that became the background and focus of this comparison study, which is communication in cross-cultural counseling, culture in the organization, and assimilation of cultural/cultural construction.

\section{Communication in Cross-Cultural Counseling}

To answer the question of what is communication in crosscultural counseling, what is the purpose, how in culture is inherent in counselors, and how willing a counselor adapts in a different culture, then we first need to deepen what that is meant by cross-cultural counseling. There are several reasons why people interact with each other in the context of intercultural counseling or can be said between different individuals or groups of cultural values. For example, a case of bullying on a Papuan student attending Java Island, crosscultural counseling comes in a special approach to resolving the problem. In that case the situation intercultural interaction is important in the functioning of counseling itself.

Cross-cultural counseling is the interaction between counsellors and counselee occurring in the dimensions between individuals who are culturally indifferent. The role of counselors who are capable of functioning in a compound environment is an awareness that they appropriately place themselves as sensitive to heterogeneous cultures. In this case the role of counseling as part of a responsive service should be consistently concerned that the counseling process is oriented on cross-cultural dimensions, both in theory and practice foundations. Cross-cultural counseling is not only limited to the interaction and communication aspects between counselors and counselee on the counseling dimension. More than that crosscultural counseling has a preventive role to the symptoms that can later arise from the behavior of students who are intolerant to the culture of other students.

Cross-cultural counseling can be threatened by psychological mechanisms expressed in stereotypical (cognitive) attitudes, bias (evaluative), and discrimination (open behavior) [1]. In the case of cross-cultural counseling at the primary school level, for example, when a child enters an elementary school environment they have been able to identify his own culture and have been able to accept his cultural values and norms. It can be influenced by social or peer to peer environment. Their understanding of the values and norms they learn will strengthen the attitude of prejudice to other cultures. Such as for example when a child treats discrimination against a friend who has a black race. To counter this, it is necessary to cross-cultural counseling programs such as intercultural relations skills training and cultural awareness.

The biggest challenge in cross-cultural counseling is how to foster confidence in the process of communication between counselors and counselee. Cultural differences between counselors and counselee should not be a barrier in crosscultural counseling. Therefore, such aspects appreciate the uniqueness of the individual, giving the rights of individuals in the self-actualization as well as the commitment of receiving the counselee from any cultural background must be owned by a counselor. With an awareness of the uniqueness of each individual, counselors are able to realize the many different characters in his social environment. Due to the most important counselee in cross-cultural counseling is how the counselee perceives that the counsellor is conscious and sensitive to its uniqueness. That would later affect the openness of counselee in counseling.

It is important for counselors to be sensitive to cultural differences. It is important to remember that the cultural differences between counselors and the counselee they possess greatly affect counseling success. Not only will it improve the effectiveness of counseling and bring closer counselors to personal counselee, but it also makes them serve as a model of counselee in behave and behave towards other cultural groups. This kind of principle is needed for beginner counselors, especially those who still attend college counselor. So in practice on their field was trained in taking a stance on the counselee with different cultural settings.

Counselors who have the same cultural background with counselee tend to have no problems in terms of communication. While the counsellor is in a different culture, they will experience a major transition in his/her life [4]. Regardless of the cultural differences counselor with the counselee, during the process of transitional problems can still be handled adequately, but the transition can lead to academic and psychological losses [10]. In particular, the problems that arise when tackling the demands of new cultural contexts, and learning new ways to overcome such cultural transitions may result in increased academic and personal pressures [10,11]. Therefore, cross-cultural counselors must have four basic 
competencies, namely self-awareness, knowledge, skills, and organizational development [12].

Self-awareness competencies relate to cultural influences on beliefs and values that they believe themselves. Knowledge competence is counsellor to know how culture affects the process and results of counseling and to understand the values of counseling practices related to certain cultural groups. Adding local language knowledge also impacts the smooth communication in cross-cultural counseling. Skill competencies include skill development through cross-cultural counseling practice as well as developing strategies to overcome cultural barriers. And the final competence is the development of the organization, where the organization can indirectly provide clear policies and procedures regarding the implementation of practical practice of cross-cultural counseling.

If looking at the dynamics formed in cross-cultural counseling, then it is crucial that counselors have all four competencies of cross-cultural counseling. These four competencies have answered the question of how important communication is in cross-cultural counseling, what is the purpose of cross-cultural counseling, how in culture adheres to counselors and affects the counseling process, and how active counselors adapt in different cultures.

\section{Culture In The Organization}

Cross-cultural research on the job world is an area that includes structural organizations related to individual job desk roles. To answer the question of cultural significance in the organization, how in culture is inherent in the personal members, and how willing they understand and adapt to other members ' cultures, then we need to formulate some criteria of values related to with individual roles in the organization or work by following a four-dimensional value formulation [13]. The four dimensions of the value are the dimensions of power distance, avoidance of uncertainty, individualism-collectivism, and masculinity-femininity. Further the characteristics of individual cultures in the four dimensions of the value should refer to the personality dimensions that describe the individual in particular.

The dimensions of power distance, this dimension refers to the extent to which individuals accept that power or leadership in the organization is not distributed evenly. This is demonstrated by some members who have a less robust position in the organizational policies as well as other stronger members.

Dimension uncertainty avoidance, this second dimension refers to how far individuals feel to get pressure or threats by uncertain and ambiguous situations. It is characterized by high levels of anxiety and aggressiveness that are capable of creating a personal boost to work harder.

The dimension of individualism and collectivism, in the dimension of individual individualism that represents the group tends to maintain distance with other organizational groups by forming a social framework for the purpose of protecting its organization, it also applies in a group that is only selfish and the closest person to seeking a safe situation. While the dimension of collectivism is characterized by a social framework that looks at that collaboration with other groups of organizations will form a tangible working force with maximal results.

The dimension of masculinity-femininity, this fourth dimension covers the measurement of individual performance concepts in the dimensions of muscularity assessed to have dominus values in terms of firmness, quality of life and matters relating to male traits. Despite a lot of opposition, the four dimensions still provide an explanation framework for a number of cultural dimension differences not only in psychology disciplines, but also in other disciplines, such as leadership and management research.

\section{CUltural AsSimilation AND CUltural CONSTRUCTION}

Acculturation is defined as a process that occurs when members of two or more cultural groups come into contact with each other and produce new cultural lessons. Cultural acculturation can be unidirectional or bidirectional, in the direction that the culture that we carry affects the culture of others, the two-way meaning of culture that we carry and others take influence on each other so that emerging culture [5,14]. In the dimension of the cross-cultural environment, individuals who still hold cultures since birth will go through various levels of cultural adaptation when living in a new environment. These self-adjustments are influenced by the level of similarity or distinction between own culture and others [15]. Acceptance of a new living environment including counselors at the school, affects the way individuals learn to respond to anything shared when people of different cultures are gathered together.

Research on acculturation is growing rapidly in response to increased migration around the world. The initial approach to acculturation, which assumes that there will be failures in the assimilation suffered by migrants to the new culture, has been widely abandoned. It is now acknowledged that immigrants can follow a variety of acculturation strategies. They can focus on aspects that they think are positive about their origin culture (such as religion). In addition, it is acknowledged that acculturation not only depends on the migrants themselves, but also on the attitudes towards the migrants in the wider community and the types of settlement policies of a country. Further diversification in research has resulted from differences in theoretical approaches that emphasize stress, cultural learning or social identification [16].

Membership of cultural groups reflects external cultures outside individuals such as food, clothing, customs, and religion, while internalized cultures reflect individual levels of enculturation such as beliefs, attitudes, and ways of thinking [8]. The main characteristics of students coming from outside the area that are those are those who are in a cross-cultural transition [4]. They must adapt to the demands of other people's culture and transition from their own culture to the culture of others. In the transition sometimes students will experience a 
cultural shock $[17,18]$. These cultural shocks spark the experience of individuals living in a different cultural environment to learn to become accustomed to the new culture. [19].

There are two main types of concerns in cultural shocks affecting cross-cultural students: (a) interpersonal factors related to the environment and surrounding environment, and (b) intrapersonal factors associated with the self-process. In addition, although individual learning experiences with cultures can run fast, they should still be faced with a variety of external or environmental problems. It includes concerns about cultural differences (e.g., norms and cultural customs), practical environmental issues (e.g., housing, universities), languages (e.g., fear of making mistakes, nonverbal behavior), experiences class (for example, feeling abandoned, difficulty speaking), and social interactions (e.g. Difficulties in developing friendships, social events are difficult to find) [11].

Issues of financial support, communication problems, cultural shock, dissonance about experience, and social support as a special issue for cross-cultural students [2]. Other researchers [5,3] has emphasized that cultural shock involves new learning to address new aspects of the new environment, such as assumptions, beliefs, and social norms for behavior.

Based on the problems that occur, researchers are interested in making a comparative study that relates between social interaction and communication in the implementation of counseling practicum at Manado State University counseling study program. The results of this comparison study are expected to help understand how the role of communication and social interaction is able to influence the characteristics of counsellors in providing problems faced with counselee.

\section{DISCUSSION}

The fundamental assumption of culture believes that the values and norms contained in a person's culture will affect the communication process in the multicultural dimension. Language is an integral part of human values and norms. In the process of communication, language differentiation becomes very important because one can be restricted by unaligned communication. The use of language in multicultural communication becomes very important, where the attitude of tolerance in communicating is born from an individual's attitude to want to learn the host language. It will later be related to cultural assimilation.

In this paper, we believe that communication in crosscultural counseling can be threatened by psychological mechanisms expressed by stereotypical, biased, and discriminatory attitudes (not accepting Counselee in full). We have also concluded that the biggest challenge in cross-cultural counseling is how to foster good communication and confidence in the communication itself. We also suggest needing mutual respect for the uniqueness of others, granting individuals the right to self-actualization, and the commitment of receiving counselee from any cultural background. Therefore, cross-cultural counselors must have four basic competencies, namely self-awareness, knowledge, skills, and organizational development.

To determine the dimension of interaction and communication in the organizational culture, we need to refer to the four dimensions of Hofstede, namely the dimensions of Power Distance, Uncertainty Avoidance, Individualismcollectivism, and masculinity-femininity. These four dimensions provide a framework not only on the psychological aspect, but also refer to management and leadership disciplines. The dimension of Hofstede is able to answer the question of this article about how much influence aspects communication in organizational culture.

This article also answers how much influence the cultural assimilation and construction of a new culture was born from an acculturation process of cross-cultural student culture with local students. They are at least capable of well through the transition process of their own culture towards others. Where the establishment of a new culture emerged when a crosscultural student focused on the aspect they thought was positive for him. However, in this article we conclude that the process of assimilation does not only occur in a single focus of time, but it can happen throughout life, as long as the individual is open to a culture that they think is positive for him. Perhaps in the forthcoming timeframe this article can offer a broader understanding of those who are becoming the next research object.

\section{CONCLUSION}

Based on the basic assumption that there are cultural differences, cross-cultural counseling is very vulnerable to stereotyping, prejudice and discrimination attitudes. Crosscultural counseling emphasizes that cultural differences must be addressed with an attitude of sensitivity and mutual respect between cultures. Because the most important in cross-cultural communication is to believe in the process of communication itself.

Cultural differences are obstacles in cross-cultural counseling. Those involved in the counseling process must adapt to the demands of the culture of others, whose effects are unconsciously involved in the process of cultural transition. These cultural transitions require someone to get used to the culture of others.

Thus, social interaction and communication in crosscultural counseling are influenced by how counselors and Counselee are able to carry the communication without cultural bias. The influence of cultural differences that each individual brings can be suppressed by appreciating the individual against its uniqueness, granting the rights of individuals in selfactualization and the commitment of receiving the Counselee from any cultural background.

Researchers also want to underline that not all cases of cross-cultural counseling can run smoothly according to the above discussion. Cross-cultural counseling can be said to be successful if the cases appearing in the context of contemplated 
[7] A. Durant and I. Shepherd, "Culture' and 'Communication' in Intercultural Communication," European Journal of English Studies, 13(2), 147-162, 2009.

problems can be solved and are able to break the effect of the domino that will potentially emerge.

\section{ACKNOWLEDGMENT}

With all due respect we pronounce sincere appreciation to the whole board of the 4th AES (Asian Education Symposium) for the opportunity that has been given to us so that this article can be published. Thank you to the Rector of Universitas Negeri Yogyakarta for all the help and support that has been given so that this article can be provided by us and publish according to the related parties. And praises only for the Lord of Hosts.

\section{REFERENCES}

[1] M.A. Alexander and E. Shaw, "International students at a College of Nursing: Concerns and coping.," Journal ofAmerican College Health, vol. 39, no. 5, pp. 245-247, 1991.

[2] N. Arthur, "Counseling issues with international students," Canadian Journal of Counseling, vol. 31, no. 4, pp. 259-273, 1997.

[3] J.G. Draguns, Humanly universal and culturally distinctive: Charting the course of cultural counseling. In P. B. Pedersen, J. G. Draguns, W. J. Lonner, \& J. E. Trimble (Eds.), Counseling across cultures (4th ed, pp. 1-20). Thousand Oaks, CA: Sage, 1996, p 1-20.

[4] N. Arthur, Counseling international students: Clients from around the world. New York, NY: Kluwer/Plenum Academic Press, 2003.

[5] J.W. Berry, Immigration, acculturation, and adaptation. Applied Psychology, 1997.

[6] H. Bowe and K. Martin, Communication across cultures: Mutual understanding in a global world. In Communication Across Cultures: Mutual Understanding in a Global World, 2007.
[8] D.Y.F. Ho, Internalized Culture, Culturocentrism, and Transcendence. The Counseling Psychologist, 1995.

[9] G. Hofstede, "Motivation, leadership, and organization: Do American theories apply abroad? Organizational Dynamics,", 1980.

[10] Y.Y. Hong, M.W. Morris, C.Y. Chiu and V. Benet-Martínez, Multiculrtiral minds: A dynamic constructivist approach to culture and cognition. American Psychologist, vol. 55, no. 7, pp. 709-720, 2000.

[11] E.J. Jacob and J.W. Greggo, "Using counselor training and collaborative programming strategies in working with international students," Journal of Multicultural Counseling and Development, 2001.

[12] F.R. Kluckhohn and F.L. Strodtbeck, Variations in value orientations. In American Sociological Review, 1961.

[13] P. Koopman, "Embedded system design issues (the rest of the story)," Proceedings International Conference on Computer Design. VLSI in Computers and Processors, pp. 310-317, 2012.

[14] S. Lysgaard, "Adjustment in a foreign society: Norwegian Fulbright grantees visiting the United States. International Social Science Bulletin,", 1995.

[15] H.R. Markus and S. Kitayama, Culture and the self: Implications for cognition, emotion, and motivation. Psychological Review, 1991.

[16] D.R. Matsumoto, The A, B, Cs of Acculturation. In Handbook of Culture and Psychology, 2001.

[17] N.J. Mckinlay, H.M. Pattison, and H. Gross, An exploratory investigation of the effects of a cultural orientation programme on the psychological well-being of international university students, Higher Education, 1996.

[18] K. Oberg, "Cultural Shock: Adjustment to New Cultural Environments," Practical Anthropology, 2017.

[19] P.B. Pedersen, Counseling International Students. The Counseling Psychologist, 1991. 